successful book that explores the fluidity between the clichéd categories of 'whore' and 'matron' through investigating a range of categories across a wide range of evidence (visual and archaeological as well as textual), interrogating stereotypes and realities with fascinating results. The ambivalence in elite Roman views of women comes to the fore, for instance in Chapter 2, looking at 'good little prostitutes'. Change is visible over time, as in Chapter 3, which focuses on 'notable courtesans and prostitutes' from the Late Republic to the Antonines, with Strong suggesting that the visible switch in consort role between wife and concubine by emperors was done in order 'to deliberately mininimize female influence' (96). Continuing the theme of ambivalence, Chapter 4 looks at the 'matrona as meretrix', considering famous figures such as Clodia and Messalina. The next two chapters move rapidly down the social scale and take on a broader range of material, including graffiti, inscriptions, and archaeological and legal evidence. One of Strong's questions here regards the visibility of prostitutes in the urban landscape, which involves taking on the vexed question of moral 'zoning' in Roman towns: Strong concludes that brother workers were 'in no way... relegated to the hidden corners of the Roman city' (170). Changing direction again, Chapter 7 , focuses on the role of prostitutes in religious life, while the final substantive but rather brief chapter looks at the legacy of the 'whore'. Strong's conclusions are worth our consideration:

The Roman discourse about matronae and meretrices shaped the lives of real women through its prescriptive message of virtuous and problematic behavior. At the same time, the actual experiences of those women undermined or directly challenged any attempt at rigid categorization. (204)

While scholarship has favoured binary distinctions, the reality - as revealed across a broad range of evidence - was more complex. Nonetheless, a sunny view of women's position in Roman culture and society remains elusive: Strong tells us that she would have liked to have written a book about how Roman women managed to get control of their lives and destinies but instead had to focus on 'the historical reality of. . patriarchal misogyny that sought to define and circumscribe the lives of Roman women' (204). This seems a rather glum note on which to end the Roman History book review, but it is certainly realistic.

LUCY GRIG

lucy.grig@ed.ac.uk doi:10.1017/S0017383518000049

\title{
Art and Archaeology
}

If asked to cite a single image as symbolic of Athenian democracy, many Classicists would probably suggest the Tyrannicides group. It seems the obvious choice. Yet while no one would deny the ideological value given to the statue(s) raised in commemoration of the event, there are some well-known historical reasons for being sceptical about any democratic ideals harboured by Harmodius and Aristogeiton when they assassinated Hipparchus in 514 BC. In that sense, the Tyrannicides group is 
inappropriate. So what alternatives come to mind? Here is one possibility, which was once visible, like the Tyrannicides, in the Athenian agora: a fourth-century BC marble relief showing several figures engaged in making footwear (Agora inv. I 7396). The piece carries an inscription, worth quoting:

Dionysios the son of [Sim?] on, the cobbler, and the children dedicated this to Heros Kallistephanos. Having seen a divine vision in his sleep, Dionysios adorns the hero and the children of Kallistephanos; do you give in return for these things wealth and happy health. ${ }^{1}$

The sculptor is unknown, and hardly of the first rank; arguably there are three generations shown in the workshop, with Dionysios central and most evidently involved in crafting a shoe, but details are indistinct. As a social statement, however, image and epigraph combine with clear significance. Seated on proper chairs (klismoi) and wearing elegant gowns (himatia), Dionysios and two sons have evidently devolved the basic chore of cutting up leather to a slave (foreground), while they do the skilled assembly; an older man, plausibly the father, holds up a finished product as if doing a final quality control before putting it on a peg, apparently with pride. We lack the image of the fair-crowned hero, probably shown reclining at a banquet (with his offspring in attendance). But we see that Dionysios, banausos though he was, had heroic connections. Like Shakespeare's 'rude mechanical', Bottom the weaver, he has had 'a most rare vision', and presumes, with this tall stele, to bargain with a demi-god for further prosperity. It seems the very soul of 'democratic' citizenship. And it is one of the 224 pieces carefully gathered in Carol Lawton's Votive Reliefs (Agora XXXVIII). ${ }^{2}$ Most of these belong to the fourth century, and many of them feature images of communion with a banqueting hero. Plato, perhaps, might see in this further proof that 'democratic man' was brutally obsessed with feeding himself. More impartially, Lawton's catalogue adds valuable evidence for the style and practice of hero-cult and regular piety at the civic heart of classical Athens.

Not long after Dionysios set up his stele in the Agora, a certain Domsalos dedicated a funerary relief in the Kerameikos (Athens National Museum 1488). Its carving, again, was not done with conspicuous technical virtuosity, but both the image and the text of the dedication are full of historical interest. The inscription is bilingual, revealing our Greek Domsalos as Domseleh, from Sidon, and his deceased friend 'Antipatros' as Shem, from another Phoenician city, Ashkelon. The image shows a figure upon a bier beset by lion, and the lion in turn attacked by another figure standing near a ship's prow. Close readings of this stele have recently been made by Jennifer Stager and Olga Tribulato; now it is set within a broader assessment of the visual evidence for Greco-Phoenician interaction in Becky Martin's The Art of Contact. ${ }^{3}$ Years ago,

\footnotetext{
${ }^{1}$ John Camp's translation, with a proposal - from Camp - that the dedicant's father may have been Simon, the cobbler known to Socrates.

${ }^{2}$ The Athenian Agora. Results of Excavations Conducted by the American School of Classical Studies at Athens. Volume XXXVIII. Votive Reliefs. By Carol L. Lawton Princeton, NJ, American School of Classical Studies at Athens, 2017. Pp. xxv +150. 12 colour illustrations, 60 plates. Hardback \$150, ISBN: 978-0-87661-238-5.

${ }^{3}$ The Art of Contact. Comparative Approaches to Greek and Phoenician Art. By S. Rebecca Martin. Philadelphia, PA, University of Pennsylvania Press, 2017. Pp. vii +282.38 colour and 59 b/w illustrations. Hardback £50, ISBN: 978-0-8122-4908-8.
} 
David Gill made a spirited case for recognizing a distinct historical reluctance on the part of classical archaeologists to acknowledge the extent of Phoenician activity within 'the Greek world'. ${ }^{4}$ Martin's tone is a little less polemical, but nevertheless pressing hard to redress an imbalance. Her range of theoretical reference is admirably wide, and she is unafraid to confront some well-known genres of 'typically Greek' artistic production: for example, the kouros-type. It is refreshing to have the 'Alexander-sarcophagus' analysed as it might have been viewed by 'elite Sidonians'. Clinching the argument that the 'Slipper-Slapper' Group from Delos deserves to be seen as a work of Phoenician, specifically 'Beiruti', sculpture, is rather more difficult. That it was found in a clubhouse on Delos used by merchants from Beirut, and that it was dedicated by a Dionysius unashamed to declare himself a grandson of one such merchant, is obviously important. But, as Martin herself concedes, 'we know very little about the artistic process anywhere in Phoenicia, either the role of artists or that of patrons' (151). What if the Phoenicians on Delos were like the Romans on Delos - apparently content to accept that 'others' (i.e. Greeks) should coax likenesses out of stone and bronze?

The Romans, wherever they were, liked to stage a good funeral. A continuing abundance of freshly excavated material is one reason why the study of the Roman funerary process is academically so 'alive', as demonstrated by a collection of new essays, Death as a Process. ${ }^{5}$ The editors draw attention to the impact of more refined analysis of skeletal and organic remains upon our understanding of ancient ritual sequences. But biomolecular microscopy is not the only advance, as revealed by a series of case studies encompassing sites such as Canterbury, Kenchreai, Pompeii, and Tiel-Passewaaij in the Netherlands. Deposited artefacts are scrutinized not so much as status indicators of the deceased but as signals of ritual sequence. A fascinating contribution from Sébastien Lepetz strives to clarify how the detritus of various foodstuffs and offerings recovered from the Porta Nocera cemetery at Pompeii relates to funerals and funerary cult. What steals the show, however, is probably the discussion of 'mass graves' located near Kalkriese in Lower Saxony. It was in 1987 that Tony Clunn, a metal-detector enthusiast serving with the Royal Tank Regiment at nearby Osnabrück, picked up a trail of Augustan coins, which in turn led to surveys and excavations along the course of a defile some 18 miles ( 30 kilometres) long. The quantity of bones - of humans and pack animals - along with thousands of fragmentary items of Roman military equipment, persuasively suggests that this was the site of the ambush and massacre of three legions in $\mathrm{AD}$ 9. Quintili Vare, legiones redde! echoes down the centuries; this reviewer will not easily forget the experience of being in a Munich Bierkeller when drinkers took up the refrain Herr Quintilius Varus, tam ta-tam tam tam! in honour of Arminius (Unser Hermann), as if the victory were only yesterday. Indeed it is relatively recently (2007) that a number of pits, located beneath a collapsed rampart, have been excavated. The results, presented here by Achim Rost and Susanne Wilbers-Rost, indicate that these may attest the pieties discharged by Germanicus, on his mission to the

${ }^{4}$ D. W. J. Gill, 'Silver Anchors and Cargoes of Oil: Some Observations on Phoenician Trade in the Western Mediterranean', PBSR 56 (1988), 1-12.

${ }^{5}$ Death as a Process. The Archaeology of the Roman Funeral. Edited by John Pearce and Jake Weekes. Studies in Funerary Archaeology. Oxford, Oxbow Books, 2017. Pp. ix +300 .

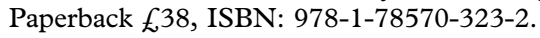


site of the disaster six years afterwards. Legions XVII, XVIII, and XIX were never re-formed. What remains of them now belongs to a multidisciplinary project involving osteologists, anthropologists, metallurgists, and more, financed by the Volkswagen Stiftung. Procurate, viri...

NIGEL SPIVEY

njs11@cam.ac.uk

doi:10.1017/S0017383518000050

\section{Philosophy}

Sarah Broadie writes on 'The Knowledge Unacknowledged in the Theaetetus' for Oxford Studies in Ancient Philosophy. ${ }^{1}$ Her paper makes two main claims: first, that Plato in the Theaetetus rejects the 'additive' picture for knowledge, namely, that knowledge is true judgement with something else (e.g. an account); and second, that in the Theaetetus true judgement relies on prior knowledge, especially if that knowledge is arrived at methodically. Thus, true judgement is not necessary for knowledge and sometimes knowledge is necessary for true judgement. Broadie's argument, roughly, is that, in the Theaetetus, true judgement is already a high-level epistemic achievement. She has a number of pieces of evidence for this. The first is Theaetetus 189e4-190a6, where Socrates stresses that a judgement is an assertion that results from a soul having a silent, internal debate. Broadie infers from this that a judgement involves reasons even if those reasons are not good reasons; judgement, for Plato, is more than a mere doxastic attitude (95-6). This already looks unfriendly to the additive picture. Once I have a judgement I have reasons, and when I have a true judgement, I have good reasons. If I have good reasons then what I have is reliable and secure. So, what more could I add to upgrade this cognitive achievement to make it knowledge? Broadie goes on to explore the alternative to the additive picture given in the Sophist and the Statesman. There it turns out that there may be topics that simply cannot be captured by the additive picture: cases where there must be knowledge of an object in the absence of true judgements about that object. This is Broadie's knowledge unacknowledged.

The Sophist provides examples. As Broadie points out, like the Theaetetus, the Sophist adopts the model of judgement as a silent assertion. If that is right, there may be cases where we need some account of a thing before we can have true judgements of that thing: cases where that thing simply does not feature in our 'conceptual vocabulary' (108). The way to get things in our conceptual vocabulary suggested by the Sophist is to locate them in a taxonomy. In general, there is no pre-theoretic grasp of objects. So, to have even true judgements of those objects, some methodical, theoretical understanding of them is needed. In these cases, of course, knowledge of an object will be necessary for judgement about it and, a fortiori, true judgement about it.

${ }^{1}$ Oxford Studies in Ancient Philosophy. Edited by Victor Caston. Vol. LI, Winter 2016. Oxford, Oxford University Press, 2016. Pp. 308. Hardback £55, ISBN: 978-0-19-879579-7; paperback $£ 25$, ISBN: 978-0-19-879580-3. For Broadie's paper, see 87-117. 